\title{
QUALITY OF LIFE OF THE ELDERLY DOMICILED IN CARPINA (PERNAMBUCO STATE, BRAZIL) DETERMINED BY BARTHEL INDEX
}

\author{
Shirley Maria Souza ${ }^{1}$; Erlaine Bernardo Silva'; Mayze Nascimento Albuquerque ; Glécio Machado \\ Siqueira ${ }^{2,}$; Joel Medeiros Bezerra ${ }^{3}$; Larissa Brandão Portela²; Danilo Madeira Campos Gonçalves4; \\ Renata Adélia Gueiros de Almeida
}

\begin{abstract}
${ }^{1}$ University Center Maurício of Nassau, UNINASSAU - Recife/PE, Brazil. ${ }^{2}$ Federal University of Maranhão, UFMA Geosciences Department. São Luís/MA, Brazil. ${ }^{3}$ Federal Rural University of the Semi-Arid, UFERSA - Mossoró/RN, Brazil. ${ }^{4}$ General Practitioner Doctor, São Luís/MA, Brazil.

${ }^{*}$ Corresponding author: gleciosiqueira@hotmail.com
\end{abstract}

\begin{abstract}
The objective of this study was to determine the quality of life in elderly Health Family Units (HFU) in Carpina (PE, Brazil) evaluated by Barthel Index and application of geostatistical tools. The main conclusions are the Barthel Index characterized the elderly of municipality as independent, with scattered cases of dependency in the elderly, being directly related frameworks of advanced age; the sampling scheme was not sufficient to detect the spatial variability of the data.
\end{abstract}

Key words: geriatric assessment, geostatistics, public health, old age, elderly dependency.

\section{QUALIDADE DE VIDA DE IDOSOS DOMICILIADOS EM CARPINA (PERNAMBUCO, BRASIL), POR MEIO DO ÍNDICE DE BARTHEL}

RESUMO: O objetivo deste trabalho foi determinar a qualidade de vida em idosos de Unidades de Saúde da Família (USF) da Cidade de Carpina (PE, Brasil) por meio do Índice de Barthel e aplicação de ferramentas de geoestatística. Como principais conclusões têm: o Índice de Barthel caracterizou o idoso do Município de Carpina como independe, havendo casos esparsos de dependência do idoso, estando relacionados diretamente com quadros de idade avançada; o esquema de amostragem não foi suficiente para detectar a variabilidade espacial dos dados.

Palavras-chave: avaliação geriátrica, geoestatística, saúde pública, idade avançada, dependência do idoso. 


\section{INTRODUCTION}

The growth of the elderly population is a worldwide phenomenon and is occurring at an unprecedented level. Data from the 2015 census of the Brazilian Institute of Geography and Statistics (IBGE) point to a population of 204.962.996 people, and the elderly over 60 years form the group with the highest growth in the past decade, accounting for $11.9 \%$ of Brazilian population (IBGE, 2015).

This is due to a reduction of fertility rates, increased life expectancy and a decrease in mortality rates (NOGUEIRA et al., 2008; MELO, 2009; RIGO et al., 2010; MINAYO, 2012). Aging is a universal, progressive and irreversible process, which causes morphological, physiological, biochemical and psychological changes (MELO, 2009). Thus the elderly becomes more susceptible to external factors and various diseases, thus losing the functional capacity leading to death (MELO, 2009; MANTELO et al., 2008; ARAÚjO et al., 2011).

Quality of life is a term with different dimensions, it depends on regions and cultures. It is related to subjective factors such as self-esteem, well-being, quality of relationships, pleasure, happiness, love and spirituality. And objective factors such as functional capacity, financial factors and material assets acquired (MIRANZI, 2008; TORRES, et al., 2009; MONTEIRO, 2010; RÊGO et al., 2012). Some elements such as longevity, biological and mental health, productivity, relationships with friends and family, cognitive efficiency and income are seen as welfare indicator in old age (TORRES et al., 2009).

The Barthel Index is one of the indexes more used to evaluate functional capacity of the elderly, it allows reliable and consistent results, evaluated by ten items of activities of daily living ( $A D L)$, dressing, bathing, eating, doing personal hygiene, up from bed and sit in a chair, bladder and bowel control, use the bathroom, walking and climbing stairs a score ranging from 0 to 100 , which will indicate the degree of dependence of the elderly (SANTOS et al., 2009; CARDOSO, 2010). The evaluation of the degree of dependence it is important to know the type of care needed and make a more accurate diagnosis according to the individual needs of each elderly.

Accordingly, should be used data analysis tools that allow the generation of public policies of health of the elderly, consistent reality of each municipality. Thus, the geostatistical have been used quite successfully in medical geography studies because it is based on a continuous stationary random function, which may be subjected to a wide range of hypothesis (SIQUEIRA, et al., 2008). In practice, the existence of stationary gives the opportunity to repeat an experiment even if the samples must be collected at different points, because they are all considered to belong to the same population and the same statistical moments (VIEIRA, 2000). The objective of this study was to determine the quality of life in elderly Family Health Units (HFU) Town of Carpina (PE, Brazil) through the Barthel Index and application of geostatistical tools.

\section{MATERIAL AND METHODS}

The study population consisted of elderly, inclusion criteria: people aged over 60 years, of both sexes, with or without some degree of dependence, as required by the Health Family 
Unit Program (HFU) of the Carpina city (PE, Brazil) (Figure 1).

The study was conducted in 10 USF of the urban area of Carpina: ESF Três Marias, Florestinha, Santo Antônio I, Santo Antônio II, Senzala, São José, COHAB, Aparecida, IPSEP, and Loteamento Santana.

The research sample consisted of 100 elderly assisted by Family Health teams in the Carpina city. Where each HFU responsible for assistance to 10 elderly, who agreed to participate. To be included in the study, elderly volunteers had to be aged 60 years and be resident in the area of the HFU over a year. They were considered as exclusion criteria the elderly who did not have good cognitive performance to answer the questionnaire, as well as those with some declared disability. Respondents were determined following the visits schedule of a Community Health Agent (CHA) of each unit of family health included in this study.

Figure 2 shows the city boundary of the municipality and the location of each of the households involved in this study.

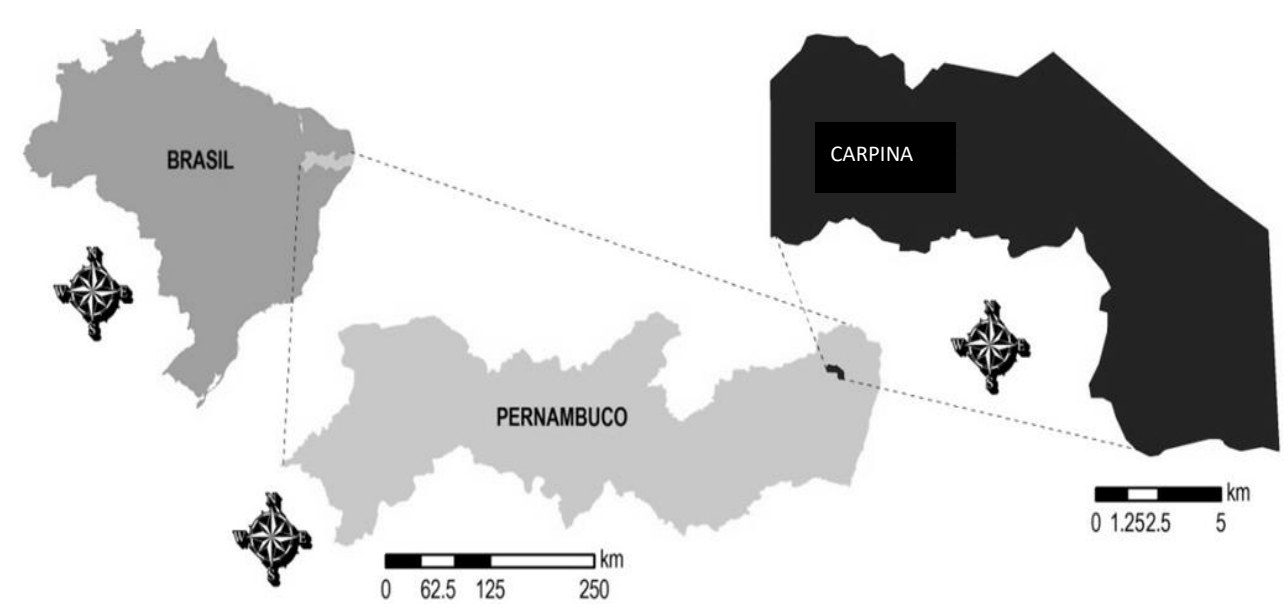

Figure 1. Location of Brazil, Pernambuco State and the Carpina city.

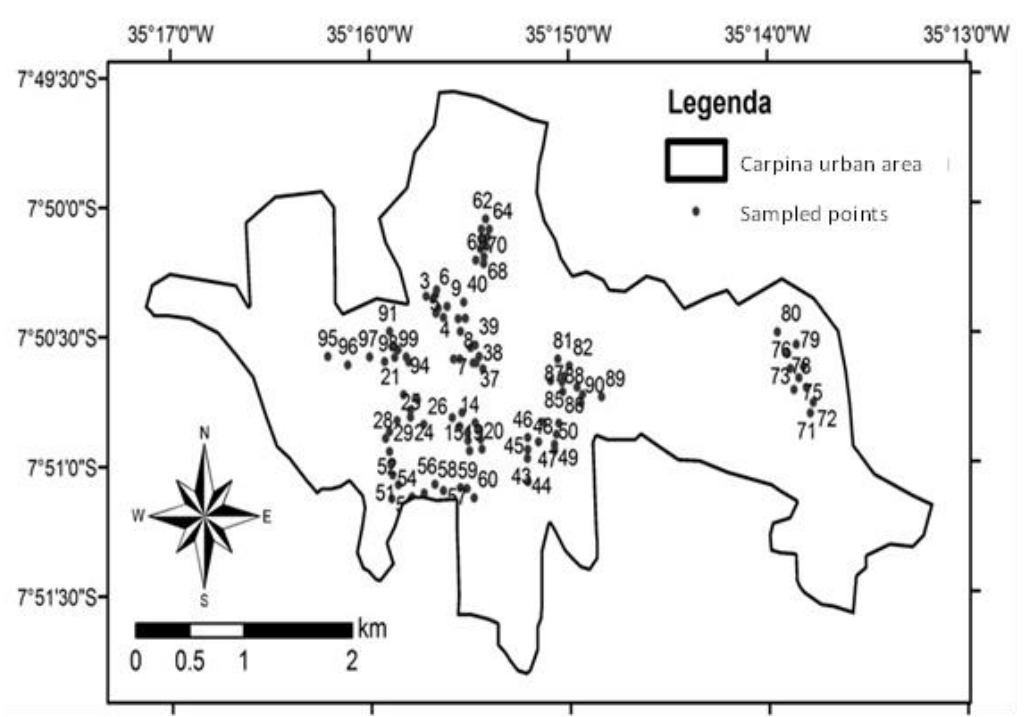

Figure 2. Urban limit of the Carpina city (PE, Brazil) and location of households involved in this study. 
The elderly volunteers will be informed about the purpose and methodology of the study and writing may be included by consent, according to Resolution 196/96 CNS.

The Barthel Index comprises ten items of mobility are the basic activities of daily living $(A D L)$ : dressing, bathing, eating, doing personal hygiene, getting up out of bed and sit in a chair, bladder and bowel control, use the bathroom, walking and climbing stairs (TORRES et al., 2009; CARDOSO et al., 2010). The activities that make up the index have been adapted in the form of questions to be answered and observed.

The cutoff points defined for the index were: 0-15 points-total dependence; 20-35 points - severe dependence; 40-55 points moderate dependence; 60-95 points - mild dependence; and 100 points - independent (TORRES et al., 2009).

A database from the field survey with 100 elderly, the sampling sites was generated (the homes visited) georeferenced, allowing the subsequent spatial these.

Data were analyzed using the SURFER 11 (GOLDEN SOFTWARE, 2012) program, to determine the main statistical moments (mean, median, minimum, maximum, variance, coefficient of variation, kurtosis, asymmetry coefficient, frequency distribution and obtain the maximum deviation from the distribution Normal ( $n$ ), or Lognormal (Ln) through the test error probability Kolmogorov-Smirnov (KS) at the $1 \%$ level of probability).

The spatial variability of the data was determined by semivariogram modeling experimental (McBRATNEY and WEBSTER, 1986; VIEIRA, 2000) considering that all values satisfy the hypothesis of stationarity (intrinsic hypothesis of geostatistics). The semivariogram was determined considering the following equation 1 :

$$
\hat{\gamma}(h)=\frac{1}{2 N(h)} \sum_{i=1}^{N(h)}\left[Z\left(x_{i}\right)-Z\left(x_{i}+h\right)\right]^{2}
$$

$\gamma(h)$ semivariance estimated; $N(h)$ - Number of observations of pairs $Z(x i), Z(x i+h)$, separated by a distance $h$.

It is understood, by geostatistical analysis, lifting the experimental semivariogram and subsequently adjusting to a family of theoretical models, allowing you to view the nature of the spatial variation of variables (JOURNEL and HUIJBREGTS, 1978; McBRATNEY and WEBSTER, 1986).

Then it was carried spatial characterization of the Barthel Index in the study area, using the amounts recorded in field survey, generating maps of isolines, using the SURFER 11 (GOLDEN SOFTWARE, 2012) software, in addition to evaluating the spatial continuity of the Barthel Index, using tools geostatistics.

The used coordinates were obtained in field survey in the visited homes, and these interpolated with the aid of a mathematical model to obtain best fit the behavior of the variable, subsequently estimated unsampled values using the semivariogram adjustment parameters by means of the technique of kriging interpolation.

\section{RESULTS AND DISCUSSION}

Table 1 presents the main statistical moments for this study. It appears that the Barthel Index had an average value of 76.950, with a minimum of 0 and maximum value of 100 , indicating the presence of the Carpina city of seniors with complete independence 
and total dependence to perform daily

activities.

Table 1. Statistical parameters for the key attributes related to the Barthel Index

\begin{tabular}{ccccc}
\hline Parameters & Index & Age & Weight & Height \\
\hline Number of values & 100 & 100 & 100 & 100 \\
\hline Minimum value & 0 & 60 & 40 & 1.4 \\
\hline Maximum value & 100 & 96 & 98 & 1.8 \\
Average & 76.950 & 72.910 & 67.610 & 1.597 \\
\hline Variance & 787.826 & 79.618 & 121.392 & 0.006 \\
\hline Standard deviation & 28.068 & 8.923 & 11.018 & 0.075 \\
Coefficient of variation & 36.5 & 12.2 & 16.3 & 4.7 \\
\hline Asymmetry & -1.387 & 0.654 & 0.485 & 0.219 \\
\hline Kurtosis & 0.877 & -0.168 & 0.676 & 1.062 \\
\hline D* & $0.206 \mathrm{Ln}$ & $0.102 \mathrm{n}$ & $0.105 \mathrm{n}$ & $0.116 \mathrm{n}$ \\
\hline
\end{tabular}

* D: maximum deviation from the normal distribution (n) or Lognormal (Ln) through the test error probability Kolmogorov-Smirnov (KS) with an error probability of $1 \%$.

Table 2. Linear correlation for parameters involved in this study.

\begin{tabular}{ccccc}
\hline & Barthel Index & Age & Weight & Height \\
\hline Barthel Index & 1.000 & & & \\
Age & -0.424 & 1.000 & 1.000 & 1.000 \\
Weight & -0.050 & -0.028 & 0.527 & 0.038 \\
Height & -0.038 & & & \\
\hline
\end{tabular}

The evaluation of the degree of dependence it is important to know the type of care needed and make a more accurate diagnosis according to the individual needs of each elderly. Commonly ranks dependence on total severe, moderate, mild and independent. A person with mild dependency needs supervision only. Since the person with moderate dependency needs supervision and support of another person to perform a certain task. The elderly with severe dependency needs ongoing support to perform activities of daily living. Finally, the person performing certain activities of daily living alone is considered independent (ARAÚjo et al., 2011).
The elderly characterized this study has an average age of about 73 years, with an average weight of $67.61 \mathrm{~kg}$ and average height of $1.59 \mathrm{~m}$. However it noted that the minimum and maximum values for the parameters age and weight varied considerably as shown by variance values (Table 1), while the height was the parameter that showed the lowest value of variance (0.006). They were now expected variance values for the Barthel Index, since the same includes all other parameters in this study, besides being an index that reflects the quality of life of the elderly, with a qualitative parameter.

The coefficient of variation is low found values for age, height and weight; and median 
for the Barthel Index, according to the classification proposed by GOMES (1984).

The skewness and kurtosis values indicate the presence of lognormal frequency distribution for the Barthel Index and normal for other parameters (age, height and weight). This fact is confirmed by the Kolmogorov-Smirnov normality test (D, Table $1)$.

The linear correlation matrix shows that the cause and effect relationship between the Barthel Index and the other parameters under study is the reverse order, especially for the Barthel Index and age $(|r|=-0.424)$. In this case, it can say that with increasing age of the elderly there is a decrease in the Barthel Index value, representing greater the of elderly's dependence degree. The parameters showed insignificant values of linear correlation when compared with the Barthel Index. The linear correlation matrix shows the weight $x$ height has a correlation value of $|r|$ $=0,527$, with a positive correlation, indicating that the greater the height, the higher the weight. However this did not reflect on the Barthel Index, as shown by the other linear correlation values.

The geostatistical analysis showed that all parameters had pure nugget effect (PNE), indicating that the sampling scheme was not sufficient to detect the spatial dependence among samples (SIQUEIRA et al., 2008; VIEIRA, 2000).

However, in this case the USF allocated in the Carpina city (PE, Brazil), does not consider all neighborhoods uniformly, occurring the presence of two islands concentration of sampled values in the urban area, one in the central area of the city and one on the east side, and corroborating the presence of PNE (Figure 2).
Figure 3 respectively shows the isolines map for the attributes under study: Barthel Index, age, weight and height; constructed by means of the parameters "default" SURFER program, which is based on a linear interpolation model by kriging (GONDEN SOFTWARE, 2012).

The isolines map to the Barthel Index shows that in the Carpina city (PE, Brazil), the elderly have mild dependence (60-95 points) or are completely independent (100 points) (TORRES et al., 2009). In some individual cases located in the central area of the city occur values less than 60 indicating moderate dependence (40-60 points), severe (20-40 points) or total (0-15 points). The presence of a greater dependence of the elderly in the central area of the city may be associated with the region further development and higher incomes, reflected in greater longevity of the elderly. When associate the weight of the maps with the height (Figure 3) can display the relationship between the dependence assessed by the Barthel Index and the higher age of the elderly, also confirming to the data presented in Table 2 (Barthel Index and Age: $|r|=-0.424)$. In this case the public policies for the elderly should be concentrated in this region, according to the lawsuit filed by isolines map (Figure 3).

The isolines map to the weight of the elderly (Figure 3) showed that there are also individual cases of most weight in central urban area. However, it is difficult to say whether this case there is a public health problem in relation to obesity, since other parameters are associated (VICTOR et al., 2009). On the other hand, the spatial weight of the elderly also provides subsidies for the determination of public health policies the elderly, because it allows understanding and 

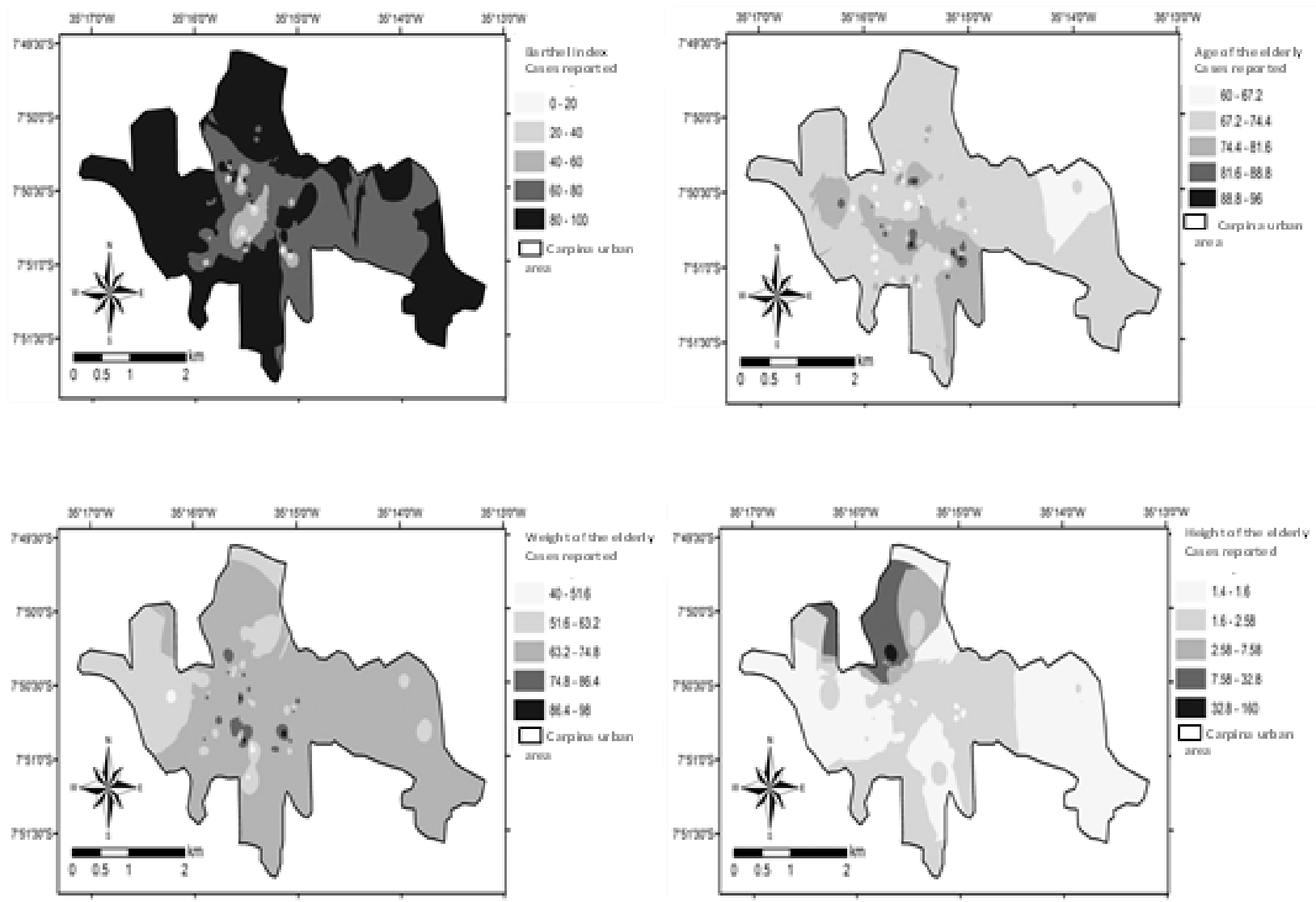

Figure 3. Isolines maps.

The height map of the elderly is itself only an indicator of the physical composition thereof, however, can be associated with weight and in turn comprises a parameter for a better understanding of possible future public health problems. There are individual cases of greater height in the northern part of the urban area.

\section{CONCLUSION}

The Barthel Index described the elderly of Carpina city as independent, with scattered cases of elderly dependency usually related to old age frames. The sampling scheme was not sufficient to detect the spatial variability in the data.

\section{REFERENCES}

Araújo, I.; Paul, C.; Martins, M. 2011. Viver com mais idade em contexto familiar: dependência no auto cuidado. Revista da Escola de Enfermagem da USP, v4, n.45, p.869-65.

Cardoso, J.H.; Costa, J.S.D. 2010. Características epidemiologias, capacidade funcional e fatores associados em idosos de um plano de saúde. Ciência e Saúde Coletiva, v.15, n.6, p.287-2878.

GOLDEN SOFTWARE. 2012. Surfer V.11. Surface Mapping System, Colorado, 2012. 
Gomes, F.P. 1984. A estatística moderna na pesquisa agropecuária. Piracicaba: Potafós, 1984. 160p.

IBGE - Instituto Brasileiro de Geografia e Estatística (IBGE). Censo 2015: IBGE; 2015.

Journel, A.G.; Huijbregts, C.J. 1978. Mining geostatistics. London: Academic Press, 1978. $600 p$.

Mantello, E.B.; Moriguti, J.C.; Rodrigues A.L.J.; Ferrioli, E. 2008. Efeito da reabilitação vestibular sobre a qualidade de vida de idosos labirintopatas. Revista Brasileira de Otorrinolaringologia, v.74, n.2, p.172-80.

McBratney, A.B.; Webster, R. 1986. Choosing functions for semivariogram sand fitting them to sampling estimated. Journal of Soil Science, v.4, n.37, p.617-639.

Melo, M.C.A. 2009. Educação em saúde como agente promotor de qualidade de vida para o idoso. Ciência e Saúde coletiva, v.1, n.14, p.1579-1586.

Minayo, M.C.S. 2012. Análise qualitativa: teoria, passos e fidedignidade. Ciência e Saúde coletiva, v.17, n.3, p.621-626.

Miranzi, S.S.C. 2008. Qualidade de vida de indivíduos com diabetes mellitus e hipertensão acompanhados por uma Equipe de Saúde da Família. Texto \& Contexto Enfermagem, v.17, n.4, p.672-9.

Monteiro, R. 2010. Qualidade de vida em foco. Revista Brasileira de Cirurgia Cardiovascular, v.25, n.4, p.568-574.

Nogueira, S.L.; Geraldo, G.M.; Machado, J.C.; Ribeiro, R.C.L. 2008. Distribuição espacial e crescimento da população idosa nas capitais brasileiras de 1980 a 2006: um estudo ecológico. Revista Brasileira de Estudos de População, v.1, n.25,p.195-198.

Rêgo, A.R.O.N.; Gomes, A.; Dantas, E.H.M. 2012. Respostas da qualidade de vida de idosas hipertensas após programa de exercício físico supervisionado. Revista Científica Internacional, v.1, n.8, p.69-98.

Rigo, I.I.; Paskulin, L.M.G.; Morais, E.P. 2010. Capacidade funcional de idosos de uma comunidade rural do Rio Grande do Sul. Revista Gaúcha de Enfermagem, v.3, n.31, p.254-61.

Santos, B.R.L.; Creutzberg, M.; Cardoso, R.F.M.L.; Lima, S.F.; Gustavo, A.S.; Veigas, K.; Welfer, M.; Souza, A.C.A. 2009. Situação vacinal e associação com a qualidade de vida, a funcionalidade e a motivação para o autocuidado em idosos. Revista Brasileira de Epidemiologia, v.12, n.4, p.1-8.

Siqueira, G.M.; Vieira, S.R.; Ceddia, M.B. 2008. Variabilidade espacial de atributos físicos do solo determinados por métodos diversos. Bragantia, v.67, n.1, p.203-211.

Torres, G.V.; Reis, L.A.; Fernandes, M.H. 2009. Qualidade de vida e fatores associados em idosos dependentes em uma cidade do interior do Nordeste. Jornal Brasileiro de Psiquiatria, v.58, n.1, p.39-44.

Victor, J.S.; Ximenes, L.B.; Almeida, P.C.; Vasconcelos, F.F. $2009 . \quad$ Perfil sociodemográfico e clínico de idosos atendidos em Unidade Básica de Saúde da Família. Acta Paulista de Enfermagem, v.22, n.1, p.49-54.

Vieira, S.R. 2000. Geoestatística em estudos de variabilidade espacial do solo. In: Novais, R.F.; Alvarez, V.H.; Schaefer, G.R. (ed.) Tópicos em Ciência do solo. Viçosa: Sociedade Brasileira de Ciência do Solo, v.1, 2000. p. 154. 